\title{
EVOLUTION OF SECRET SERVICES IN THE THIRD POLISH REPUBLIC - HISTORICAL AND LEGAL CONDITIONS
}

\begin{abstract}
One of the main tasks of public authorities is to ensure the safety of citizens, which depends on the actions undertaken within the country and beyond its borders. The ongoing process of increasing globalization causes that the security authorities should constantly anticipate, detect and neutralize threats. The world security depends mainly on the geopolitical, economical and social situation. The army and police participation in international organizations causes that detection of threats is more effective. Important role in securing the country against terrorism, corruption and organized crime fulfil the authorities conducting the activities secretly. Secret services are institutions of particular importance in the structure of the public authority regardless of the political system. They are separate piece of the government administration. From the transformation period in 1989 until today Polish secret services institutions were changed many times. Over the years, it was necessary to adapt their organization to dynamic political conditions, democratic political system of Poland and current national needs. The aim of this publication is analyse the role of special services in the Third Polish Republic. The first stage includes the analysis of the process of transformation of military and civilian secret services of Polish People's Republic after 1989. The next are described the changes made in the twenty-first century. An analysis contains legal aspects of the existing five Polish secret services: Internal Security Agency, Intelligence Agency, Military Counterintelligence Service, Military Intelligence Service and Central Anticorruption Bureau.

Keywords: secret services, intelligence, counterintelligence, anticorruption, internal security, external security, state, defence, protection, terrorism.
\end{abstract}

\section{INTRODUCTION}

Secret services play an important role in the country, ensuring its internal and external security regardless of the political system. This thesis is confirmed by the Security Service (SB), which was a security body in the People's Republic of Poland (PRL) responsible for internal and external protection of the communist system. The Security Service was a body which was very effective in its activities for its principal and certainly just by its effectiveness, but also controversial, often brutal methods of operation, is considered to be one of the most sinister symbols of PRL. ${ }^{2}$ The beginning of the institutionalization of contemporary Polish secret services dates back to 1940s towards the end of the Second

${ }^{1}$ Tomasz Lewandowski, MA in political science, Kazimierz Wielki University in Bydgoszcz, email: lewandowski.bydgoszcz@wp.pl

${ }^{2}$ https://www.abw.gov.pl/pl/o-abw/historia/282,GENEZA.html [access: 6.02.2015]. 
World War. ${ }^{3}$ Reference to the then security authorities is important because over the years these entities have evolved and their transformation led to the creation of secret services currently operating in the Third Polish Republic. An analysis of the transformation of secret services in Poland requires, first of all, determining what they are and what their role is. Secret services are a separate organizational piece of the state, which forms part of the government administration. They perform part of tasks constitutionally assigned to the Council of Ministers and government administration and related to the protection of the interests of the State Treasury, ensuring internal and external security of the state and public order. ${ }^{4}$ On the one hand, secret services are often identified only with performing intelligence and counterintelligence activities. On the other hand, due to their competences they are often confused with other uniformed formations operating in the structures of the Republic of Poland. Therefore, it should be clearly stated that secret services can only refer to those institutions that have been statutorily named as such. ${ }^{5}$ Currently, Poland has only five institutions that have been given the status of secret services by the legislator: Internal Security Agency, Intelligence Agency, Military Counterintelligence Service, Military Intelligence Service and Central Anticorruption Bureau. This means that all formations, whose job is to protect the security of the state, and which are not included in a closed directory of secret services, belong to a group of the so-called "police services". 6

\section{DEMOCRATISATION}

The aim of this publication is to analyse the secret services created as a result of the political changes after 1989. The process of democratization of the state that started then, apart from a thorough reconstruction of the system, also included among other things the transformation of the authorities responsible for its safety. In 1990 the communist apparatus of Security Service was dissolved and on 6 April 1990 the Office for State Protection (UOP) was created, as a civilian special department responsible for the internal and external protection of Poland. ${ }^{7}$ It should be noted, however, that the officers of SB did not become by law officers of UOP because, according to article 131 of the Law on Office for State Protection, at the time the Office was created they were dismissed from service. Every officer of SB, however, had the right to apply for admission to UOP, the Ministry of Internal Affairs or other organizational units subordinate to the Minister of Internal Affairs under the terms of Resolution No. 69 of the Council of Ministers of 21 May 1990. ${ }^{8}$ Only officers of SB who passed the verification process before a qualifying committee

${ }^{3}$ Z. Grzegorowski, Special services and the security of Poland, Torun 2013, p. 46.

${ }^{4}$ The Polish Constitution of 2 April 1997, Art. 146 par. 4, (Journal of Laws 1997 No. 78, item. 483).

${ }^{5}$ M. Bożek et al., Special services in the structure of public authorities, Warszawa 2014, pp. 15-16.

${ }^{6} \mathrm{Ibid}$, p. 16. The 'police services' include: Police, Government Protection Bureau, the Border

Guards, the Prison Service, the Customs Service, and the Military Police. Ibid, p. 19.

${ }^{7}$ The Act of 6 April 1990 on the Office for State Protection, (Journal of Laws 1990 No. 30, item. 180). The provision concerning the dissolution of the Security Service upon the creation of the Office for State Protection was included in Art. 129 of the Law on Office for State Protection.

${ }^{8}$ The Resolution No 69 of the Council of Ministers of 21 May 1990 on the procedure and conditions for the reception of former officers of the Security Service to serve in the Office for State Protection and other organizational units subordinate to the Minister of Internal Affairs and employing them in the Ministry of Internal Affairs, (M.P. 1990, No. 20, item. 159). 
and received a positive opinion could be employed in these services. Qualification of candidates for service in UOP and work in the Ministry of Internal Affairs or services subordinated to the Ministry of Internal Affairs was carried out by special committees created for this purpose: Central Qualifying Committee, Qualifying Committee of Central Personnel Affairs and provincial qualification committees. ${ }^{9}$ UOP was established to protect the security of the state and its constitutional order. The main tasks of the Office assigned by the legislator included: identifying and counteracting of threats against the Polish state detrimental to its security, defence, sovereignty and unity; prevention, detection and prosecution of espionage, terrorism and other crimes against the state; identification and prevention of violations of state secrets; preparation of information relevant to national security and analyses for the highest authorities and state administration. Detailed tasks of the Office and its structure were defined by the Prime Minister at the request of the Minister of Internal Affairs. ${ }^{10}$ Such a provision is fully justified because the details of the operation of secret service due to its effectiveness should be included in the acts, which for the security of the state are classified. In the Act on the UOP the legislator referred to the secret services subordinate to the Minister of National Defence, with whom UOP was obliged to cooperate in combating crimes against the Republic. ${ }^{11}$ The duties resulting from the range of UOP activities were performed by officers. In this regard, they were entitled to operational-reconnaissance and investigative powers. The officers were also entitled to procedural rights of police officers under the provisions of the Code of Criminal Procedure, i.e. checking identity documents, detention, searching people and premises, making personal inspection, baggage and cargo checks as well as requesting necessary assistance from individuals and institutions. ${ }^{12}$ UOP was headed by the Chief appointed by the Prime Minister at the request of the Minister of Internal Affairs after consulting the Political Advisory Committee to the Minister of Internal Affairs. The Chief of UOP had the status of the central state administration body, subordinate to the Minister of Internal Affairs. ${ }^{13}$

\footnotetext{
${ }^{9} \mathrm{Ibid}, \S 1$. CQC was appointed by the Prime Minister and was presided over by the Chief of UOP. The Chief of UOP was responsible for appointing the Qualifying Committee of Central Personnel Affairs and its chairman. The Chairman of CQC (Chief of UOP) also appointed provincial qualifying committees and their chairmen. Central Qualifying Committee supervised the qualification proceedings, the Qualifying Committee of Central Personnel Affairs and provincial committees. Moreover, its task was to hear appeals from the lower-level committees and to submit reports on the qualification proceedings to the Council of Ministers. The competences of the Qualifying Committee of Central Personnel Affairs included conducting proceedings and issuing opinions on the candidates who previously served at the central level. Provincial committees dealt with qualification and issuing opinions on candidates for officers who so far served in other organizational units of SB. Ibid, § 2-5.

${ }^{10}$ The Law on Office for State Protection..., Art. 1.

${ }^{11} \mathrm{Ibid}$, Art. 2. Special services subordinated to the Minister of National Defence shall be described later in this publication.

12 Ibid, Art. 6-7.

${ }^{13}$ The Law on Office for State Protection..., Art. 4; Political Advisory Committee to the Minister of Internal Affairs was created by the Regulation of the Council of Ministers of 9 July 1990. The Committee's task was to advise and issue opinions to the Minister on matters within his competence and with respect to subordinate bodies. The Committee, chaired by the Minister of Internal Affairs, consisted of 7 to 9 persons appointed by the Prime Minister at the request of the Minister. The
} 
The period of political transformation also led to the transformation of the military secret services. Changes in this case occurred in several stages and in practice consisted in merging previously independent intelligence and counterintelligence services into a single entity. As a result of the reorganization of the Internal Military Service (WSW) a division responsible for counterintelligence was eliminated, the number of field units and many posts were reduced. ${ }^{14}$ In April 1990 Internal Military Service was dissolved and the II Board of Intelligence and Counterintelligence of the General Staff of the Polish Army was created together with the Military Police, a law enforcement body extracted from the investigative and preventive department of WSW. On 22 August 1991 another rereorganization of the services subject to the Minister of National Defence was made. Then, in place of the II Board of Intelligence and Counterintelligence the Military Information Services (WSI) ${ }^{15}$ were created. A thorough transformation of the Internal Military Service was caused by the need for decommunisation of the organization, which was perceived by the society as an apparatus of oppression. The II Board of General Staff of the Polish Army, which was an intelligence service, due to the foreign area of operation was not negatively perceived by the society. Although the transformation of military secret services was carried out in several stages, it was not as thorough as it was in the case of the Security Services. This was certainly due to the activities of the communist politicians who, knowing that the fate of SB was sealed, wanted to maintain their influence at least in the military intelligence and counterintelligence services. This situation meant certain weakness of the co-ruling solidarity activists in Poland. Although they led to the dissolution of the Security Service, the liquidation of the military secret services was carried out only partially. Military intelligence was so hermetic that its existing officers essentially retained their positions and thus partial control of the state. ${ }^{16}$ It should be noted that as a result of the merging of military secret services, the positions of counterintelligence were filled with the existing intelligence soldiers. On account of then transformations the military counterintelligence was deprived of procedural rights, which in turn led to a weakening of secret services subordinated to the Minister of National Defence. $^{17}$

Military Information Services were a new secret service with combined powers of intelligence and counter-intelligence. Important is the fact that for more than ten years they operated only on the basis of internal regulations of the Minister of National Defence and amended in December 1991 the Act of 21 November 1967 on Universal Duty to

Regulation of the Council of Ministers of 9 July 1990 on the appointment of the Political Advisory Committee to the Minister of Internal Affairs and giving it the statute, § 1-3, (Journal of Laws1990 No. 47, item. 279).

${ }^{14}$ Z. Grzegorowski, op. cit., pp. 55-56. Internal Military Service was a counterintelligence organization, ensuring the safety of the Armed Forces and sustaining military discipline. http://inwentarz.ipn.gov.pl/archivalCollection?id_a=3689\&id_pz=20581 [access: 12.02.2015]. ${ }^{15} \mathrm{http}: / /$ www.skw.gov.pl/historia.htm [access: 8.02.2015];

http://inwentarz.ipn.gov.pl/archivalCollection?id_a=12797 [access: 8.02.2015];

http://www.zw.wp.mil.pl/pl/40.html [access: 7.02.2015]. Z. Grzegorowski, op. cit., p. 56. Military Police was not an organization with a secret service status.

${ }^{16}$ T. Kosobudzki, Why is secret police a problem of the Republic of Poland, Warszawa 2007, p. 76.

${ }^{17}$ Z. Grzegorowski, op. cit., pp. 55-56. 
Defend the Republic of Poland. ${ }^{18}$ The tasks of the Military Information Services included, among other things: identifying and countering threats detrimental to Polish defence, violations of the state secrets concerning defence and preparing information and analyses relevant to the defence for the state authorities. It was found that the responsibilities and activities of officers of UOP also apply to WSI soldiers in relation to their tasks. The legislator gave the Minister of National Defence competences concerning WSI that had earlier been assigned to the Minister of Internal Affairs in relation to the Office for State Protection. ${ }^{19}$ The detailed legal regulations concerning the operation of WSI were determined on 9 July 2003, nearly three years before their liquidation. At that time the law on the Military Information Services ${ }^{20}$ was passed, which directly determined that WSI are differentiated and specialized special service for the protection of the state set up to provide the national defence and security of the Polish Armed Forces. ${ }^{21}$ The legislator assigned the Military Information Service a number of tasks, which included: identification, prevention and combating risks affecting the independence and security of the state, the integrity of its territory, inviolability of borders and the defence and security of the Armed Forces. ${ }^{22}$ The legislator also defined the competence of WSI to recognize, prevent and detect crimes subordinate to the jurisdiction of military courts, which included: espionage, terrorism, and crimes against the protection of classified information relating to the national defence, offenses related to scientific research, development as well as production and arms trade. WSI were also obliged among other things to acquire, collect, process, analyse and report to competent authorities information relevant to the national defence as well as combat capability and safety of the Polish Armed Forces along with identifying and analysing risks in sensitive areas. WSI provided protection of military units and soldiers on duty and were also engaged in radio-electronic intelligence and counter-intelligence and cryptological protection. ${ }^{23}$ The Chief of WSI was appointed and dismissed by the Minister of National Defence after consulting the President of the Republic of Poland, the Prime Minister, the Collegium for Secret Services and the Parliamentary Committee for Secret Services. ${ }^{24}$ The courses of action of WSI were defined by the Minister of National Defence. During the execution of their duties, WSI were obliged to cooperate with the General Staff of the Polish Army, other units of Ministry of National Defence and army commanders of different categories. The legislator also obliged WSI to cooperate with the authorities, services and institutions under the minister responsible for foreign affairs, internal affairs, public finances and the authorities with powers of operational-reconnaissance intelligence. ${ }^{25}$

\footnotetext{
18 The Act of 21 November 1967 on the universal duty to defend the Republic of Poland, (Journal of Laws 1992 No. 4 item. 16, as amended).

${ }^{19}$ The Act of 21 November 1967 on the universal duty to defend the Republic of Poland, Art. 15, (Journal of Laws 1992 No. 4 item. 16, as amended).

${ }^{20}$ The Act of 9 July 2003 on the Military Information Services, (Journal of Laws 2003 No. 139, item. 1326).

${ }^{21}$ Ibid, Art. 1. WSI were part of the Polish Armed Forces.

${ }^{22}$ Ibid, Art. 3.

${ }^{23}$ Ibid.

${ }^{24}$ Competences of the Collegium for Secret Services and the Parliamentary Committee for Secret Services shall be described later in this publication.

${ }^{25}$ The Act on Military Information Services..., Art. 4-6.
} 
The turn of the century was a period of the next major rebuilding of Polish secret services. The need to re-reform these extremely important institutions was noticed in the late 1990s when there was a growing dissatisfaction with the operational capacity of services and final results of their work. Then a plans of reform was prepared, which assumed among other things the need to stop the process of excessive autonomization of services and as a result strengthening the control over their functioning. It was found that for the proper execution of operational tasks of secret services and to prevent interpenetration of competence, it is necessary to form a body coordinating their action. It was also recognized that it is necessary to separate the intelligence structures from counter-intelligence. Reforms on the functioning of public administration, including secret services, were carried out by means of the Act of 8 August $1996 .{ }^{26}$ The result of the then changes was the exclusion of the Office for State Protection from the structure of the Ministry of Internal Affairs and subordinating the Chief of the Office to the Prime Minister. Changes in the system of secret services were necessary also because of the Polish accession to NATO and in view of the approaching period of accession to the European Union. Polish political situation required among other things adaptation of the activities of secret services to international standards in terms of exchange of classified information $^{27}$.

\section{NEW CENTURY, NEW IDEAS}

Subsequent changes in the area of secret services of the Third Polish Republic were carried out in the twenty-first century. The first of these was the dissolution of the Office for State Protection and separation of two independent departments from its structures. On 24 May 2002 two competence separate institutions were created - the Internal Security Agency (ABW) responsible for internal protection of the state and its constitutional order and the Intelligence Agency (AW) responsible for external security of the country. ${ }^{28}$ Both of these agencies function in the Polish system of secret services until today as institutions of the state administration. They are headed by central government agencies, who report directly to the Prime Minister. ${ }^{29}$ Statutorily defined subordination of Heads of Agencies to the Prime Minister means that the ABW and AW are not departmental secret services because they do not report directly to the Minister of Internal Affairs or the Minister of National Defence, and therefore do not function within a particular department of government administration. The Prime Minister has the competence to define the guidelines for courses of action of ABW and AW. The result of this solution is the fact

26 The Act of 8 August 1996 Regulations introducing laws reforming the functioning of the economy and the state administration, (Journal of Laws 1996 No. 106, item. 497). The reform in relation to secret services, in addition to changing the competences of the Minister of Internal Affairs and the Office for State Protection, also included the liquidation of the Political Advisory Committee to the Minister of Internal Affairs and appointed in its place the Collegium for Secret Services. Ibid, Art. 1-3. Competences of the Collegium for Secret Services shall be described later in this publication.

${ }^{27}$ Z. Grzegorowski, op. cit., pp. 56-57; http://www.abw.gov.pl/pl/o-

abw/historia/284,LATA19962002.html [access: 9.02.2015].

${ }^{28}$ The Act of 24 May 2002 on the Internal Security Agency and the Intelligence Agency, (Journal of Laws of 2002 No. 74, item. 676).

${ }^{29}$ Ibid, Art. 3. 
that both agencies are among the so-called "civil secret services". The practice of direct subordination of the Heads of ABW and AW to the President of the Council of Ministers indicates that the Prime Minister has the right to carry out supervision and perform actions arising from the employment relationship towards the Heads of Agencies by his coworkers, typically in the person of a member of the Council of Ministers Coordinator of Secret Services, secretaries and undersecretaries of the state. ${ }^{30}$ The Prime Minister also has the right to entrust supervisory function over civilian secret services to departmental ministers. This is confirmed by the fact that according to the Regulation of the President of the Council of Ministers in 2011 the function of the coordinator of secret services was entrusted to the Minister of Internal Affairs Jacek Cichocki, ${ }^{31}$ and in 2014 to Bartlomiej Sienkiewicz. ${ }^{32}$ The delegation of supervisory and coordinating powers, however, does not cause that the competences of secret services are subject to the Minister of Internal Affairs, as in $\S 2$ of both Regulations it was concluded that the minister exercises supervision over the services and coordinates their actions on behalf of the President of the Council of Ministers and under his authority. ${ }^{33}$ In 2014 the rules of supervision and coordination of secret services were changed because the function of coordinator was entrusted to the Minister - Member of the Council of Ministers, ${ }^{34}$ separating this function from the competence of Teresa Piotrowska, appointed to the office of the Minister of Internal Affairs. ${ }^{35}$

${ }^{30}$ M. Bożek et al., Secret services in the structure of public authorities, Warsaw 2014, pp. 46-47. Ibid, Art. 7.

${ }^{31}$ The Regulation of the President of the Council of Ministers of 24 November 2011 on the detailed scope of activities of Jacek Cichocki - Minister of Internal Affairs for coordination of secret services, (Journal of Laws 2011 No. 254, item. 1524).

32 The Regulation of the President of the Council of Ministers of 28 February 2013 on the detailed scope of activities of Bartłomiej Sienkiewicz - Minister of Internal Affairs - for coordination of secret services, (Journal of Laws 2013 item. 272). By means of the two Regulations, the Prime Minister entrusted J. Sienkiewicz and B. Cichocki the role of coordinator of the Internal Security Agency, Intelligence Agency, and also the Central Anticorruption Bureau, the Military Intelligence Service and the Military Counterintelligence Service, whose genesis and the scope of responsibilities shall be described later in this publication.

${ }^{33}$ The authorization of the Minister J. Cichocki and B. Sienkiewicz as coordinators of secret services resulted from Art. 33 par. 1 of the Act of 1 August 1996 on the Council of Ministers, (Journal of Laws Act of 2012, item. 392). The content of Art. 33, paragraph 1 specifies that: "The President of the Council of Ministers shall establish by way of regulation: a detailed scope of activity of the minister, immediately after the appointment of the Council of Ministers, and if the minister was appointed at a different time - immediately after his appointment."

${ }^{34}$ The Regulation of the President of the Council of Ministers of 23 September 2014 on the detailed scope of activity of the Minister - Member of the Council of Ministers Jacek Cichocki for coordination of secret services, (Journal of Laws 2014 item. 1276). Coordinator of secret services was again Jacek Cichocki, but as a Minister in the Chancellery of Prime Minister and not as a departmental minister.

${ }^{35}$ As is apparent from those three Regulations, supervision and coordination done on behalf of the President of the Council of Ministers consists in, inter alia, ensuring the cooperation of all secret services, obtaining information from them, dealing with legislative matters relating to special services. In terms of direct employment relationship of the Chiefs of: ABW, AW and CBA, the Minister authorized to supervise and coordinate services, performs all activities except for appointing and dismissing them from office. 
An essential task of the Internal Security Agency is to protect Poland against activities that may pose a threat to the independence or constitutional order of the state and which may interfere with the functioning of state structures and expose the fundamental interests of the country to losses. ${ }^{36}$ In addition, the Internal Security Agency is committed to fight and prosecute: terrorism, economic crime, corruption threatening the interests of the state and organized crime. The essential tasks of the Agency include prevention of the proliferation of weapons of mass destruction, counter-intelligence activities, protection of classified information and conducting analytical and informational activity. ABW activity abroad is possible only in connection with prosecuting the described crimes. ${ }^{37}$

Intelligence Agency was established for the implementation of tasks abroad. Its activity on the territory of the Republic of Poland can be carried out solely to a limited extent, only in connection with its activities abroad. ${ }^{38}$ The ultimate task of AW is its activities to ensure the external security of the state, independence, territorial integrity, international position and economic potential as well as defence of the state. Furthermore, the competences of the Agency, among other things, include: protection of overseas representations of Poland and their workers from the operation of foreign intelligence services and activities threatening the interests of the state. The Agency's responsibilities also include provisions relating to: ensuring the protection of cryptographic communication with Polish diplomatic and consular posts as well as security of the courier service. An important task of AW is to recognize and counteract terrorism, extremism, organized crime, arms trade, trading of goods and services prohibited or strategic to national security and recognise dangers posed by weapons of mass destruction. Furthermore, AW is engaged in electronic intelligence as well as recognising, analysing and eliminating hazards in critical areas of the world. ${ }^{39}$

The first years of the twenty-first century also brought major changes in the organization of military secret services. Although the transformation of civilian secret services consisting in liquidation of UOP and appointment of separated from each other ABW and AW took place without undue controversy, the last period of operation of the Military Information Services caused some criticism of this service. WSI were accused of, among other things, exceeding their powers and sluggishness in the verification of staff originating in majority from the communist period. While dissolution of the communist counter-intelligence was successful, a substantial part of the military intelligence remained intact. It is worth noting that the new military counter-intelligence was created based on existing, unverified officers. In 2006 the process of liquidation of WSI and creation of new military secret services began. ${ }^{40}$ For this purpose a law was passed on the Regulations implementing the Act on the Military Counter-intelligence Service and the Military Intelligence Service and the law on the service of officers of the Military Counter-intelligence Service and the Military Intelligence Service. ${ }^{41}$ Its provisions

\footnotetext{
${ }^{36} \mathrm{http}: / /$ www.abw.gov.pl/pl/zadania/63,Zadania.html [access: 10.02.2015].

37 The Act on Internal Security Agency ..., Art. 5.

${ }^{38} \mathrm{http} / / / \mathrm{www}$. aw.gov.pl/pol/agencja/przedmiot-dzialania-agencji.html [access: 10.02.2015].

${ }^{39}$ The Act on Internal Security Agency ..., Art. 6.

${ }^{40} \mathrm{http}: / /$ www.skw.gov.pl/historia.htm?lev1=0\&lev2=0 [access: 9.02.2015].

${ }^{41}$ The Act of 9June 2006. Regulations implementing the Act on the Military Counterintelligence Service and the Military Intelligence Service and the Act on the service of officers of the Military
} 
appointed Plenipotentiaries for the organization of the Military Counter-intelligence Service and the Military Intelligence Service as well as a Liquidation Committee for the liquidation of WSI and a Verification Committee. The legislator specified that the Military Information Services shall be abolished on 30 September $2006 .{ }^{42}$ Military Counter-intelligence Service (SKW) and the Military Intelligence Service (SWW) were established on 1 October 2006 by the law of 9 September 2006 on the Military Counterintelligence Service and the Military Intelligence Service. ${ }^{43}$ Both services were created to protect the country against threats to its defence, security, combat capability of the Armed Forces and other units subordinate or supervised by the Minister of National Defence. SKW in this respect is the service responsible for protection of the state against internal threats and SWW against external ones. ${ }^{44}$ Both secret services operate in Poland until today. The Heads of SWW and SKW are central governmental agencies, subordinate to the Minister of National Defence, subject to the described competences of the Prime Minister to confer supervisory and coordination functions to the Minister Coordinator of Secret Services. The lines of action of SKW and SWW are set out by the Minister of National Defence. In the case of the appointment of the Minister Coordinator these lines are agreed by the Minister of National Defence and the Minister Coordinator of Secret Services, and then approved by the President of the Council of Ministers. ${ }^{45}$ The main tasks of the Military Counter-intelligence Service, among other things, include: prevention, detection and recognition of crimes committed by soldiers, officers of SWW and SKW, personnel of Polish Armed Forces and other units subordinated to the Minister of National Defence. ${ }^{46}$ As far as law enforcement is concerned, SKW is obliged to cooperate with the Military Police. The tasks of SKW include: obtaining, collecting, analysing, processing and reporting to the relevant authorities of information relevant to the internal security of the state; electronic counter-intelligence activities; cryptographic protection; participation in the planning of international disarmament agreements; protection of units and soldiers subordinated to MON; protection of research, development, manufacturing and marketing of goods and services essential for the military. ${ }^{47}$ Military Intelligence Service in order to ensure the safety of the country's defence capabilities, safety and combat capability of the Armed Services and the conditions for the implementation of foreign tasks of Armed Services is committed to obtaining, collecting, analysing, processing and reporting of relevant information to the competent authorities. In addition, the tasks of SWW, among other things, include: identifying and preventing external military threats detrimental to the national defence, terrorism; identifying the international trade in arms and other

Counterintelligence Service and Military Intelligence Service, (Journal of Laws 2006 No. 104, item. 711).

42 Ibid, Art. 57-58

43 The Act of 9 June 2006 on the Military Counterintelligence Service and the Military Intelligence Service, (Journal of Laws 2006 No. 104, item. 709).

${ }^{44}$ Ibid, Art. 1-2.

${ }^{45} \mathrm{Ibid}$, Art. 3, Art. 7. SKW and SWW are government administration bodies. Ibid, Art. 3.

${ }^{46}$ The legislator specified that the tasks of SKW relate to, among others, crimes against: peace, humanity, the Republic of Poland, protection of classified information. More information: Ibid, Art. 5 par. 1 point 1 .

${ }^{47} \mathrm{Ibid}$, Art. 5 par. 1 point 2-8. SKW deals with the detection and recognition of crimes committed with the help of persons subjected to MON. Its activities abroad are only permitted in conjunction with national powers. Ibid, Art. 5, par. 3 
materials, technologies and services prohibited or strategic to the national security. ${ }^{48}$ SWW is obliged to identify and analyse the risks in the critical parts of the world, conduct electronic intelligence and cryptographic operations for the Armed Forces; co-organise military representations abroad, participate in the planning and control of the implementation of international agreements concerning disarmament. ${ }^{49}$ The legislator accepted the possibility of cooperation of SKW and SWW, but its mode and form are determined by the regulations of the Minister of Defence, which are not subject to announcement. It was also provided that the Heads of both services can collaborate with the services which are their counterparts abroad, but such cooperation requires the consent of the Prime Minister, who is obliged to consult the Minister of National Defence beforehand. SKW and SWW carrying out their activities may also cooperate with the General Staff of the Polish Army, MON departments, the commanders of the Armed Forces as well as districts, garrisons and units; with the authorities, services and institutions reporting to the Minister responsible for internal affairs, for public finance, foreign affairs and other authorities, services and institutions with powers of operational intelligence. ${ }^{50}$ The Heads of SKW and SWW are appointed and dismissed by the Prime Minister at the request of the Minister of National Defence after consultation with the Collegium for Secret Services and the Parliamentary Committee for Secret Services. Opinions of the two bodies are forwarded to the President of the Republic of Poland for opinion. The legislator provided the opportunity to appoint to the position of the Heads of SKW and SWW people who are not active soldiers and officers of these services. ${ }^{51}$

The creation of SKW and SWW in 2006 was not the only significant event concerning the functioning of secret services, since an entirely new secret service was also created Central Anticorruption Bureau (CBA), with competences that were previously in a wide range of tasks of the Internal Security Agency. ${ }^{52} \mathrm{CBA}$ was set up to combat corruption in the political and economic life, with particular emphasis on public institutions - state and local government, and to combat any activity which harms the economic interests of Poland. ${ }^{53}$ In Art. 1 the legislator defined the concept of corruption and the activities detrimental to the interests of the state. ${ }^{54}$ The main tasks of CBA in the fight against corruption and activities detrimental to the economic interests of the state, among other things, include: prevention, identification, detection and prosecution of perpetrators of

\footnotetext{
${ }^{48}$ Ibid, Art. 6.

${ }^{49}$ Ibid.

${ }^{50} \mathrm{Ibid}$, Art. 10.

${ }^{51}$ Ibid, Art. 13, Art. 15.

52 The Law of 9 June 2006 on the Central Anticorruption Bureau, (Journal of Laws 2006 No. 104, item. 708).

${ }^{53} \mathrm{http}: / /$ www.cba.gov.pl/pl/o-cba/347,O-CBA.html [access: 12.02.2015].

${ }^{54}$ Corruption laws defined by the legislator as: "promising, offering, giving, requesting, receiving by any person, directly or indirectly, of any undue pecuniary, personal or otherwise, for oneself or any other person, or accepting an offer or promise of such benefits in exchange for action or omission in the performance of public functions or in the course of economic activity". The Law on the Central Anticorruption Bureau ... Art. 1 par. 3 The definition of the activities detrimental to the interests of the state, determined any behavior that may cause significant damage as defined in the Criminal Code to the property of units: the public sector; private sector, if these units receive public funding; entrepreneurs with the Treasury of the State or the local government units. Ibid, Art. 1, par.
} 4. 
crimes against: public institutions (state and local government), justice, elections, referendum, credibility of documents, business transactions and money and securities, party financing, tax obligations and settlements from grants and subsidies, if they are due to corruption or activity against the economic interests of the State. ${ }^{55}$ In relation to these offenses, CBA is authorized to pursue its activities abroad. ${ }^{56}$ In addition, CBA has the competence to, among others: disclose and combat any failure to observe the restrictions of commercial activities by public officials; disclose non-compliance with procedures related to privatization, commercialization, providing: public procurement, concessions, reductions, quotas. The task of $\mathrm{CBA}$ is to control the asset declarations and declarations of public persons concerning business activity in terms of accuracy and authenticity. The Bureau is required to pursue analytical activities of phenomena within its competence and present the results to the Prime Minister, President of the Republic of Poland and the two Chambers of Parliament. ${ }^{57}$ The legislator decided that public administration and state institutions are obliged in terms of their activities to cooperate and assist the Central Anticorruption Bureau. Moreover, the provisions of the law provide for the possibility of cooperation of CBA within its jurisdiction with international organizations. ${ }^{58}$ Central Anticorruption Bureau, as a government administration office, is headed by the Chief, who is a central body of government administration as in the case of Heads of ABW, AW, SKW and SWW. The Head of CBA is supervised by the President of the Council of Ministers. The position of the Head of CBA, in contrast to other heads of secret services, is elective. The Head of CBA is appointed by the Prime Minister for four-year terms. Appointment and removal is performed after consultation with the President of the Republic of Poland, the Collegium for Secret Services and the Parliamentary Committee for Secret Services. The Head of CBA may be reappointed only once. ${ }^{59}$ CBA operates on the basis of a statute defining its internal organization given by the Prime Minister. The Prime Minister also determines in the form of guidelines the directions of CBA activity. ${ }^{60}$ It should be noted that the legislator granted a wide range of powers to officers of this service. In order to prevent, detect and identify crimes they may carry out operational and investigative activities. If there is a suspicion of committing a crime, they have the right to perform investigative activities. Officers carry out control operations to expose corruption in public life and in the case of activities against the economic interests of Poland. In order to obtain and process information relevant to combat crimes falling under the competences of the Bureau, they also carry out analytical and informational activities as well as operational and investigative activities. ${ }^{61}$

The Law on the Central Anticorruption Bureau entered into force 30 days after its announcement. Within seven days of its notification Prime Minister was obliged to appoint Plenipotentiary for the organization of CBA. ${ }^{62}$ Transitional provisions defined

\footnotetext{
55 The Law on Central Anticorruption Bureau ..., Art. 2 par. 1 point 1.

${ }^{56} \mathrm{Ibid}$, Art. 2, par. 4.

${ }^{57}$ Detailed scope of powers of CBA the legislator listed exhaustively detailing the legal basis in Art.

2 of the Act on the Central Anticorruption Bureau.

${ }^{58} \mathrm{Ibid}$, Art. 2 par. 2 Art. 3.

${ }^{59}$ Ibid, Art. 5-6.

${ }^{60} \mathrm{Ibid}$, Art. 11-12.

${ }^{61}$ Ibid, Art. 13

${ }^{62}$ The Law on Central Anticorruption Bureau ... Art. 214 par. 216
} 
also, among other things, that the Internal Security Agency within 18 months from the declaration of the act on CBA can perform preparatory proceedings and other proceedings initiated and unfinished on the identification, prevention and detection of crime of corruption of public officials where it can threaten the security of the State. After this time, the powers concerning corruption offenses under the provisions of the act were to be withdrawn from ABW. ${ }^{63}$ On 20 December 2007, four days before the entry into force of this provision, the legislator passed a law amending the law on Internal Security Agency and Intelligence Agency, in which the powers of ABW to identify, prevent and detect crime of corruption were restored. The functioning in Poland of two secret services with anticorruption powers suggests that corruption in public life is a phenomenon occurring on a large scale. In order to fight corruption, in 2008 the Chancellery of the President of the Council of Ministers prepared the so-called "anticorruption shield". Its assumption was to create prevention mechanisms against corruption practices in the following areas: privatization of State Treasury and public procurement carried out by ministries at the value of more than 20 million PLN. Activities under "anticorruption shield" are coordinated by the Chancellery of the President of the Council of Ministers and its activities engage ministries involved in the project and all Polish secret services. ${ }^{64}$

In order to ensure the proper functioning of the secret services and control over them the legislator established two bodies with different competences. The first of these is the Collegium for Secret Services. ${ }^{65}$ This body, which currently operates on the basis of the law on Internal Security Agency and the Intelligence Agency as well as the Regulation of the Council of Ministers of 2 July 2002 on the detailed procedure and rules of the Collegium for Secret Services and the scope of activities of the secretary of this Collegium; the work regulations of the Collegium for Secret Services. ${ }^{66}$ Collegium in matters of programming, monitoring and coordination of secret services is an advisory body of the Council of Ministers. As far as protection of the security of the state is concerned Collegium has identical competences to: the police, Border Guards,

\footnotetext{
${ }^{63} \mathrm{Ibid}$, Art. 211, Art. 216 in relation to: The Act on Internal Security Agency ..., Art. 5 par. 1 point 2 letter $\mathrm{c}$.

${ }^{64} \mathrm{https}: / /$ www.abw.gov.pl/pl/zadania/zwalczanie-korupcji/tarcza-antykorupcyjna/61,Tarczaantykorupcyjna.html [access: 11.02.2015];

https://www.premier.gov.pl/wydarzenia/aktualnosci/szczegolowe-informacje-dotyczace-tarczyantykorupcyjnej.html [access: 11.02.2015].

${ }^{65}$ Collegium for Secret Services was established in place of the Political Advisory Committee to the Minister of Internal Affairs as evidenced by Art. 3 of the Act of 8 August 1996. Regulations introducing laws reforming the functioning of the economy and the state administration, (Journal of Laws 1996 No. 106, item. 497). The tasks and the mode of operation of Collegium for Secret Services were defined in the Regulation of the Council of Ministers of 10 June 1997 on the tasks, detailed rules and procedures of Collegium for Secret Services at the Council of Ministers, the rules for participation in the meetings of Collegium of representatives of secret services and other competent authorities, as well as the scope of activities of the Collegium Secretary, (Journal of Laws 1997 No. 64, item. 412)

66 The Act on Internal Security Agency ..., Section 2; The Regulation of the Council of Ministers of 2 July 2002 on the detailed procedure and rules of operation of Collegium for Secret Services and the scope of activity of the Collegium Secretary, (Journal of Laws 2002 No. 103, item. 929); http://bip.kprm.gov.pl/kpr/bip-rady-ministrow/organy-pomocnicze/organy-pomocniczerady/119,Kolegium-do-spraw-Sluzb-Specjalnych.html [access: 15.02.2015].
} 
Government Protection Bureau, Military Police, Prison Service, Customs Service, reconnaissance services of the Polish Armed Forces, offices, chambers and bodies of fiscal control; authorities of financial information. ${ }^{67}$ The tasks of the Collegium also include formulation of assessments and opinions on: appointment and dismissal of the heads of all secret services; directions and plans of activities of secret services; drafts of normative acts and other government documents relating to the operation of secret services; detailed budget projects of secret services; performing by secret services assigned tasks; annual reports submitted by the Chiefs; protection of classified information. ${ }^{68}$ The work of Collegium is chaired by the President of the Council of Ministers. It consists of a secretary and other members: the minister responsible for internal affairs, the minister responsible for foreign affairs, the Minister of National Defence, the minister responsible for public finances, the Chief of the National Security Bureau and, if appointed - the minister for coordinating the activities of secret services. The meetings of the Collegium are also attended by heads of all five secret services and the Chairman of the Parliamentary Committee for Secret Services. ${ }^{69}$

An advisory-control body with respect to secret services is a standing Parliamentary Committee for Secret Services, whose functioning is provided in the Rules of the Sejm of the Republic of Poland. ${ }^{70}$ The scope of its activities, among other things, includes: opinions on draft laws and other legal acts relating to secret services, evaluation of policies and examining annual reports of their heads; opinions on draft budget for these services and reviewing reports on its implementation. The competences of the Committee also include: giving opinions on the appointment of heads of secret services and their deputies, familiarising with information of secret services concerning particularly important events of their activities, including suspicion of abnormalities in the activities of secret services and infringement of law by these services; assessment of cooperation of secret services with other bodies, services and institutions authorized to protect national security and with public institutions. ${ }^{71}$ The number of members of the Committee is determined by the Sejm upon the request of the Presidium. Its meetings are confidential. ${ }^{72}$

\section{CONCLUSION}

The above analysis shows that from the transformation period in 1989 until today Polish secret services were subject to many extensive organizational changes. It is worth mentioning that their structure and working methods were generally adequate to the requirements of the system in which they operated at any given time. Over the years, it was necessary to adapt their organization to dynamic political conditions, democratic political system of Poland and current national needs. On the one hand, the task of secret services is external security of the state exercised by military and civilian intelligence

\footnotetext{
${ }^{67}$ The Act on Internal Security Agency ..., Art. 11.

${ }^{68}$ Ibid, Art. 12, par. 1.

${ }^{69} \mathrm{Ibid}$, Art. 12, par. 2. The meeting may also be attended by other people. Ibid, Art. 12, par. 4-5.

70 The Resolution of the Sejm of the Republic of Poland of 30 July 1992. Regulations of the Sejm of the Republic of Poland, Art. 18, (M.P. 1992, No. 26, item. 185.

${ }^{71} \mathrm{http}: / /$ www.sejm.gov.pl/sejm7.nsf/agent.xsp?symbol=KOMISJAST\&Nr Kadencji=7\&KodKom=KSS [access: 13.02.2015].

${ }^{72}$ Regulations of the Sejm of the Republic of Poland..., Art. 137, Art. 139.
} 
agencies. On the other, they must be organized and managed in such a way as to fulfil their role in terms of changing internal threats. Adaptation of secret services to social, economic and political changes is complicated, because the processes taking place in Poland and worldwide are highly dynamic and methods of attack on the basics of statehood increasingly sophisticated. In such a situation, it is important that the activities of secret services, regardless of their profile and scope of activity, are mutually coordinated. For internal and external security of the state is possible only if competence separated secret services cooperate with each other, responding in time to any threats to its stability.

\section{REFERENCES}

Legal acts:

[1] The Polish Constitution of 2 April 1997, (Journal of Laws 1997 No. 78, item. 483).

[2] The Act of 6 April 1990 on the Office for State Protection, (Journal of Laws 1990 No. 30, item. 180).

[3] The Resolution No 69 of the Council of Ministers of 21 May 1990 on the procedure and conditions for the reception of former officers of the Security Service to serve in the Office for State Protection and other organizational units subordinate to the Minister of Internal Affairs and employing them in the Ministry of Internal Affairs, (M.P. 1990, No. 20, item. 159).

[4] The Regulation of the Council of Ministers of 9 July 1990 on the appointment of the Political Advisory Committee to the Minister of Internal Affairs and giving it the statute, (Journal of Laws1990 No. 47, item. 279).

[5] The Act of 21 November 1967 on the universal duty to defend the Republic of Poland, (Journal of Laws 1992 No. 4, item. 16, as amended).

[6] The Act of 9 July 2003 on the Military Information Services, (Journal of Laws 2003 No. 139, item. 1326).

[7] The Act of 8 August 1996 Regulations introducing laws reforming the functioning of the economy and the state administration, (Journal of Laws 1996 No. 106, item. 497).

[8] The Act of 24 May 2002 on the Internal Security Agency and the Intelligence Agency, (Journal of Laws of 2002 No. 74, item. 676).

[9] The Regulation of the President of the Council of Ministers of 24 November 2011 on the detailed scope of activities of Jacek Cichocki - Minister of Internal Affairs for coordination of secret services, (Journal of Laws 2011 No. 254, item. 1524).

[10] The Regulation of the President of the Council of Ministers of 28 February 2013 on the detailed scope of activities of Bartłomiej Sienkiewicz - Minister of Internal Affairs - for coordination of secret services, (Journal of Laws 2013, item. 272).

[11] The Act of 1 August 1996 on the Council of Ministers, (Journal of Laws Act of 2012, item. 392).

[12] The Regulation of the President of the Council of Ministers of 23 September 2014 on the detailed scope of activity of the Minister - Member of the Council 
of Ministers Jacek Cichocki for coordination of secret services, (Journal of Laws 2014, item. 1276).

[13] The Act of 9 June 2006. Regulations implementing the Act on the Military Counterintelligence Service and the Military Intelligence Service and the Act on the service of officers of the Military Counterintelligence Service and Military Intelligence Service, (Journal of Laws 2006 No. 104, item. 711).

[14] The Act of 9 June 2006 on the Military Counterintelligence Service and the Military Intelligence Service, (Journal of Laws 2006 No. 104, item. 709).

[15] The Law of 9 June 2006 on the Central Anticorruption Bureau, (Journal of Laws 2006 No. 104, item. 708).

[16] The Regulation of the Council of Ministers of 10 June 1997 on the tasks, detailed rules and procedures of Collegium for Secret Services at the Council of Ministers, the rules for participation in the meetings of Collegium of representatives of secret services and other competent authorities, as well as the scope of activities of the Collegium Secretary, (Journal of Laws 1997 No. 64, item. 412).

[17] The Regulation of the Council of Ministers of 2 July 2002 on the detailed procedure and rules of operation of Collegium for Secret Services and the scope of activity of the Collegium secretary, (Journal of Laws 2002 No. 103, item. 929).

[18] The Resolution of the Sejm of the Republic of Poland of 30 July 1992. Regulations of the Sejm of the Republic of Poland, (M.P. 1992, No. 26, item. 185).

Books:

[1] Grzegorowski Z., Special services and the security of Poland, Grado, Torun 2013.

[2] Bożek M., Czuryk M., Karpiuk M., Kostrubiec J., Special services in the structure of public authorities, LEX, Warszawa 2014.

[3] Kosobudzki T., Why is secret police a problem of the Republic of Poland, Zetka, Warszawa 2007.

Websites:

[1] https://www.abw.gov.pl/pl/o-abw/historia/282,GENEZA.html [access: 6.02.2015]

[2] http://inwentarz.ipn.gov.pl/archivalCollection?id_a=3689\&id_pz=20581 [access: 12/02/2015]

[3] http://www.skw.gov.pl/historia.htm [access: 8.02.2015]

[4] http://inwentarz.ipn.gov.pl/archivalCollection?id_a=12797 [access: 8.02.2015]

[5] http://www.zw.wp.mil.pl/pl/40.html [access: 7.02.2015]

[6] http://www.abw.gov.pl/pl/o-abw/historia/284,LATA19962002.html [access: 9.02.2015]

[7] http://www.abw.gov.pl/pl/zadania/63,Zadania.html [access: 10.02.2015]

[8] http://www.aw.gov.pl/pol/agencja/przedmiot-dzialania-agencji.html [access: 10.02.2015]

[9] http://www.skw.gov.pl/historia.htm?lev1=0\&lev2=0 [access: 9.02.2015]

[10] http://www.cba.gov.pl/pl/o-cba/347,O-CBA.html [access: 12.02.2015]

[11] https://www.abw.gov.pl/pl/zadania/zwalczanie-korupcji/tarczaantykorupcyjna/61,Tarcza-antykorupcyjna.html [access: 11.02.2015] 
[12] https://www.premier.gov.pl/wydarzenia/aktualnosci/szczegolowe-informacjedotyczace-tarczy-antykorupcyjnej.html [access: 11.02.2015]

[13] http://bip.kprm.gov.pl/kpr/bip-rady-ministrow/organy-pomocnicze/organypomocnicze-rady/119,Kolegium-do-spraw-Sluzb-Specjalnych.html [access: 15.02.2015]

[14] http://www.sejm.gov.pl/sejm7.nsf/agent.xsp?symbol=KOMISJAST\&Nr Kadencji=7\&KodKom=KSS [access: 13.02 .2015 ]

\section{EWOLUCJA SŁUŻB SPECJALNYCH W III RZECZYPOSPOLITEJ POLSKIEJ - UWARUNKOWANIA HISTORYCZNE I PRAWNE}

Jednym $\mathrm{z}$ podstawowych zadań organów władzy publicznej jest zapewnienie bezpieczeństwa obywateli, które zależy od działań podejmowanych wewnatrz państwa oraz poza jego granicami. Trwający proces wzmożonej globalizacji powoduje, że organy bezpieczeństwa muszą nieustannie przewidywać, wykrywać i neutralizować zagrożenia. Bezpieczeństwo na świecie zależy głównie od sytuacji geopolitycznej, ekonomicznej i społecznej. Uczestnictwo wojska i policji w międzynarodowych organizacjach sprawia, że wykrywanie zagrożeń jest bardziej skuteczne. Istotną rolę w zabezpieczeniu państwa przed terroryzmem, korupcją i przestępczością zorganizowaną pełnią organy prowadzące działania o charakterze niejawnym. Tajne służby sa instytucjami o szczególnym znaczeniu w strukturze władz publicznych, niezależnie od obowiązującego systemu politycznego. Są one oddzielną częścią organizacyjną administracji rządowej. Od okresu transformacji w 1989 roku aż do dziś polskie służby specjalne były przedmiotem wielu zmian organizacyjnych. Z biegiem lat, konieczne było dostosowanie ich organizacji do zmieniających się warunków politycznych, nowego demokratycznego systemu politycznego Polski i aktualnych potrzeb krajowych. Celem niniejszej publikacji jest analiza roli służb specjalnych w III Rzeczypospolitej Polskiej. Pierwszy etap obejmuje analizę procesu transformacji wojskowych i cywilnych służb specjalnych Polskiej Rzeczypospolitej Ludowej po 1989 r. Następnie opisano zmiany dokonane w XXI wieku. Analizie poddano prawne aspekty funkcjonowania wszystkich pięciu współczesnych polskich służb specjalnych: Agencji Bezpieczeństwa Wewnętrznego, Agencji Wywiadu, Służby Kontrwywiadu Wojskowego, Służby Wywiadu Wojskowego oraz Centralnego Biura Antykorupcyjnego.

Słowa kluczowe: służby specjalne, wywiad, kontrwywiad, antykorupcja, bezpieczeństwo wewnętrzne, bezpieczeństwo zewnętrzne, państwo, obrona, ochrona, terroryzm.

DOI:10.7862/rz.2015.hss.8

Przesłano do redakcji: styczeń 2015

Przyjęto do druku: czerwiec 2015 